\title{
MERANCANG PERANGKAT LUNAK PEMBELAJARAN AL QUR'AN DENGAN METODE INTERAKTIF UNTUK ANAK
}

\author{
Khairunnisa $^{1}$ \\ ${ }^{1}$ Dosen Tetap Sekolah Tinggi Teknik (STT) Harapan Medan \\ Jl. Pancing Ling.VIII Psr.IV Gg. Genjer No.52 Mabar Hilir Medan Telp. 082244797662, Fax. 20242 \\ ${ }^{1}$ khaiunnisajv2@gmail.com
}

\begin{abstract}
Learning to read Quran with the correct way to recognize hijaiyah letters, recitation law and short letters on juz amma' is important in the introduction to the children. So far, most of us think how to pronounce the sound of reading the Qur'an properly without having to call a teacher. Therefore, this study aimed at generating media multimedia-based learning with interactive methods to give new impetus to the child who wants to learn to read the Qur'an in accordance with the correct pronunciation and recitation, and equipped with writing Arabic, Latin and voice narration, Multimedia based software allows students see the letter, letters displayed also listen to the pronunciation of the software used. In designing this software authors use Adobe Flash CS3 programming, which is able to assist authors in designing and modifying an effective software. With the creation of this software then increasing the students to learn and limitations of the teaching force can also be overcome.
\end{abstract}

Keywords: Learning Media, Multimedia, Adobe Flash CS3, how to read, recognize letters and recitation hijaiyah

\section{INTISARI}

Belajar membaca Quran dengan cara yang benar untuk mengenali huruf hijaiyah, hukum pembacaan dan surat-surat singkat tentang juz amma 'penting dalam pendahuluan kepada anak-anak. Sejauh ini, kebanyakan dari kita berpikir bagaimana cara mengucapkan bunyi membaca Alquran dengan benar tanpa harus memanggil seorang guru. Oleh karena itu, penelitian ini bertujuan untuk menghasilkan bahasa Arab, Latin dan suara media pembelajaran berbasis bahasa Arab Narration, perangkat lunak berbasis Multimedia memungkinkan siswa untuk melihat hurufnya, huruf digunakan untuk mendengarkan pengucapan perangkat lunak yang digunakan. Dalam perancangan software ini penulis menggunakan pemrograman Adobe Flash CS3, yang mampu membantu penulis dalam merancang dan memodifikasi perangkat lunak yang efektif. Dengan terciptanya software ini, motivasi belajar siswa dan keterbatasan tenaga pengajar juga bisa diatasi.

Kata Kunci : Media Pembelajaran, Multimedia, Adobe Flash CS3, bagaimana membaca, mengenali dan membaca huruf hujaiyah

\section{PENDAHULAUN}

Seiring dengan perkembangan teknologi yang canggih saat sekarang ini, perkembangan pendidikan untuk anak harus kita perhatikan. Biasanya anak-anak lebih menyukai dan cepat tangkap saat belajar dengan gambar-gambar atau tampilan dalam bentuk dimensi dibandingkan dengan membuka buku. Untuk mempermudah agar anak-anak tidak malas dalam proses pembelajaran khususnya membaca Al-Qur'an dan juga membantu anak remaja yang masih belum mengenal huruf hijaiyah, maka penelitian akan dibuat tampilan yang interaktif dan menarik. Dengan alasan tersebut maka perangkat lunak ini dibuat untuk alat bantu pembelajaran Al-Qur'an dengan menggunakan Adobe Flase CS3.

Dalam perkembangannya, inovasi teknologi sudah menjadi bagian yang tidak terpisahkan dengan dunia pendidikan. Adanya dukungan teknologi dibidang pendidikan, membuat guru terbantu dalam upaya meningkatkan kualitas pembelajaran. Dalam Pembelajaran, guru yang menggunakan teknologi dapat mempercepat, mempermudah, dan memperlan- car proses perencanaan, pelaksanaan, dan evaluasi dalam pembelajaran. AgriSains (2014)[194]

Dalam pembelajaran, media memegang peranan penting dalam mencapai sebuah tujuan belajar. Hubungan komunikasi antara pengajar dengan pelajar akan lebih baik dan efisien jika menggunakan media. Media dalam proses belajar mengajar memiliki dua peranan penting, yaitu media sebagai alat bantu mengajar atau disebut sebagai dependent media karena posisi media disini sebagai alat bantu (efektivitas), dan media sebagai sumber belajar yang digunakan sendiri oleh peserta didik secara mandiri atau disebut dengan independent media (Lisda, Seto Mulya 2014 [1]).

\section{TINJAUAN PUSTAKA}

\section{A) Pengertian Perangkat lunak}

Perangkat lunak adalah perintah (Program Komputer) yang apabila dieksekusi memberikan fungsi dan unjuk kerja seperti yang diinginkan. Struktur data yang memungkinkan program 
memanipulasi informasi secara proposional dan dokumen yang menggambarkan operasi dan kegunaan program. Perangkat lunak yang biasanya disebut dengan software juga merupakan data elektronik yang disimpan sedemikian rupa oleh komputer itu sendiri, data yang disimpan ini dapat berupa program atau instruktur yang akan dijalankan oleh perintah, maupun catatan-catatan yang diperlukan oleh komputer untuk menjalankan perintah yang dijalankannya. Untuk mencapai keinginannya tersebut dirancanglah suatu susunan logika, logika yang disusun ini doilah melalui perangkat lunak yang disebut juga dengan program beserta data-data yang diolahnya.

\section{B) Pengertian Al-Qur'an}

Al-Qur'an menurut bahasa berarti bacaan atau yang dibaca. Menurut istilah, Al-Qur'an adalah wahyu Allah Subhanahu wa ta'ala yang diturunkan kepada nabi Muhammad Shallallahu 'alaihi wasallam melalui malaikat Jibril 'Alaihissalam sebagai petunjuk bagi umat manusia. Al-Qur'an diturunkan untuk menjadi pegangan bagi mereka yang ingin mencapai kebahagian dunia dan akhirat. Al-Qur'an menggunakan bahasa Arab dan merupakan mukjizat bagi rasul. Sebagian besar ayat-ayat Al-Qur'an diturunkan di kota Mekah dan kota Madinah. Isi yang terkandung dalam Al-Qur'an terdapat 6236 ayat 114 surat dan 30 juz (M.Yanyan, Irawan 2013[2]).

\section{1) Pembelajaran Al-Qur'an}

Salah satu instrumen paling penting yang ada dalam kegiatan belajar-mengajar adalah materi pembelajaran atau bahan ajar. Boleh dikatakan bahan ajar ini menempati urutan pertama dalam daftar instrumen pembelajaran. Tanpa guru boleh jadi siswa dapat belajar dengan cara membaca bahan ajar.

Kita ketahui juga saat ini masih banyak remajaremaja yang masih belum bisa membaca Al-Qur'an bahkan tidak mengenal huruf hijaiyah, maka bahan ajar multimedia ini sangat membantu mereka untuk belajar mandiri tanpa harus membayar guru sehingga membuat mereka tidak malu untuk memulai belajar Al-Qur'an.

\section{2) Huruf Hijaiyah dan Bacaan Hijaiyah}

Terdapat 29 huruf dasar (Asas/asli) didalam AlQur'an dan 2 huruf pengganti yang dikenal juga dengan nama huruf-huruf hijaan atau hijaiyah, seperti ditunjukkan pada Tabel 1.

\section{3) Pengertian dan Hukum Ilmu Tajwid}

Pengertian Tajwid menurut bahasa (etimologi) adalah memperindah sesuatu. Sedangkan menurut istilah Ilmu Tajwid adalah pengetahuan tentang kaidah serta cara-cara membaca Al-Qur'an dengan sebaik-baiknya. Tujuan ilmu tajwid adalah memelihara bacaan Al-Qur'an dari kesalahan dan perubahan serta memelihara lisan (mulut) dari kesalahan membaca. Belajar ilmu tajwid itu hukumnya fardhu kifayah, sedangkan membaca AlQur'an dengan baik (sesuai dengan ilmu tajwid) hukumnya Fardhu 'Ain. Kita ketahui dalam melafazkan Al-Qur'an jika cara membacanya salah maka arti bacaan akan berbeda, oleh karena itu dianjurkannya untuk mengetahui cara baca dalam AlQur'an dengan mempelajari hukum tajwid (Hasan, 2008 [3]).

Tabel 1. Huruf Hijaiyah

\begin{tabular}{|c|c|c|c|c|c|c|c|}
\hline Huruf & Bacaan & Huruf & Bacaan & Huruf & Bacaan & Huruf & Bacaan \\
\hline 1 & Alif & ذ & Dzal & ظ & Zha & 9 & Wau \\
\hline 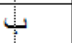 & $\mathrm{Ba}$ & J & $\mathrm{Ra}$ & $\varepsilon$ & 'Ain & 0 & $\mathrm{Ha}^{\prime}$ \\
\hline+ & $\mathrm{Ta}$ & j & Zay & $\dot{\varepsilon}$ & Ghain & J & Lam-Alif \\
\hline 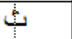 & Tsa & س & Sin & ف & $\mathrm{Fa}$ & & Hamzah \\
\hline t & Jim & ش & Syin & ق & Qaf & ي & $\mathrm{Ya}$ \\
\hline t & $\mathrm{Ha}$ & ص & Shad & ك) & Kaf & & \\
\hline$\frac{1}{d}$ & Kha & ضن & Dhad & r & Mim & & \\
\hline 4 & Dal & b & Tha & ن & Nun & & \\
\hline
\end{tabular}

\section{4) Hukum Bacaan Al-Qur'an}

Waqaf dari sudut bahasa artinya berhenti/ menahan, menurut istilah tajwid memutuskan suara diakhir kata untuk bernafas sejenak dengan niat meneruskan kembali bacaan. Jenis-jenis waqaf adalah Lazim, Jaiz, Muraqabah, Mamnuu', Saktah Latifah.

Qalqalah menurut bahasa berarti getaran, menurut istilah tajwid getaran suara yang terjadi ketika mengucapkan huruf yang sukun sehingga menumbulkan semacam aspirassi suara yang kuat, baik sukun asli ataupun tidak. Huruf Qalqalah ada 5 yaitu: Syarat Qalqalah adalah hurufnya harus sukun, baik sukun asli atau yang terjadi karena berhenti pada huruf qalqalah. Tingkatan qalqalah adalah rendah, sedang dan keras.

Ikhfa berarti samar-samar Artinya apabila ada Nun sukun atau Tanwin bertemu dengan salah satu huruf hijaiyyah yang berjumlah 15 huruf yaitu : sin, qof, syin, jim, kaf,tsa, dhal, shod, dhodh, dlodh, ta', fa', za, tho', dan dal, maka hukum bacaannya adalah ikhfa' (menyamarkan bacaan antara izhar dan idhghom).

Idhaam adalah Apabila ada Nun Sukun/ Tanwin bertemu dengan salah satu huruf hijaiyah yang berjumlah 4 huruf, antara lain: Wau, Mim, Nun, dan Ya.

Izhaar. Hukum Izhar Cara membacanya terang atau jelas. Didalam Al-Qur' an huruf Izhar ada 6 yaitu: Ha, Kho, 'Ain, Ghoin, Ha', dan Hamzah. 
Mad menurut bahasa berarti tambahan, menurut istilah tajwid memanjangkan suara sewaktu membaca huruf mad atau huruf lain jika bertemu dengan hamzah atau sukun. Huruf mad terbagi dengan3, yaitu alif, waw dan ya. Syarat mad adalah huruf sebelum waw bebaris dhammah, sebelum ya berbaris kasrah dan sebelum alif fatha. Jika sebelum ya atau wau sukun itu berbaris fathah, maka tidak disebut mad, akan tetapi disebut huruf lain, pembagian Mad ada 2 yaitu Mad Asli dan Mad Far'i.

Iqlaab yaitu apabila ada nun mati atau tanwin bertemu dengan huruf ba' maka hukum bacaannya adalah iqlab (mengganti tanwin atau nun mati dengan huruf mim).

\section{C) Metode Pembelajaran}

Tri Anjaya (2013) [4] mengatakan Metode Pembelajaran adalah cara yang dapat digunakan untuk melaksanakan strategi pembelajaran. Berdasarkan pendapat tersebut dapat dijelaskan bahwa metode merupakan upaya yang digunakan untuk mengimplementasikan rencana yang sudah disusun dalam kegiatan nyata untuk mencapai tujuan pembelajaran. Metode digunakan untuk merealisasikan strategi yang telah ditentukan. Penerapan satu strategi pembelajaran memungkinkan untuk diterapkannya beberapa metode pembelajaran.

\section{D) Pendidikan Anaka Usia Dini}

Pendidikan anak usia dini (PAUD) merupakan suatu upaya pembinaan yang ditujukan bagi anak sejak lahir sampai dengan usia delapan tahun (Rista Apriana, 2009 [5]).

Pendidikan ini dapat dilakukan dalam jalur pendidikan sekolah maupun pendidikan luar sekolah, dan bentuk pendidikan pun dapat dilakukan di Taman Kanak-Kanak, Play Group, Tempat Penitipan Anak atau di TKA/TPA dan RA.

\section{E) Media Pembelajaran}

Kata media adalah bentuk jamak dari medium yang berasal dari bahasa latin medius, yang berarti "tengah". Dalam bahasa Indonesia, kata "medium" dapat diartikan sebagai antara atau selang. Pengertian media mengarah pada sesuatu yang mengantar meneruskan informasi (pesan) antara sumber (pemberi pesan) dan penerima pesan (Hasrul, 2011 [6]).

Namun demikian, media bukan hanya berupa alat atau bahan saja, akan tetapi hal-hal yang memungkinkan siswa dapat memperoleh pengetahuan.

\section{F) Multimedia}

M. Yanyan, Irawan 2013 [2] mengatakan Multimedia adalah media yang menggabungkan dua unsur atau lebih media yang terdiri dari teks, grafik, gambar, audio, video dan animasi secara terintegrasi.. Multimedia terbagi menjadi dua kategori yaitu :

1. Multimedia Linier adalah suatu multimedia yang tidak dilengkapi dengan alat pengontrol apapun yang dapat dioperasikan oleh pengguna. Multimedia linier berjalan secara sekuensial. Contoh dari multimedia linier adalah TV dan Film.

2. Multimedia Interaktif adalah suatu multimedia yang dilengkapi dengan alat pengontrol yang dapat dioperasikan oleh pengguna sehingga pengguna dapat memilih apa yang dikehendaki untuk proses selanjuntya. Contoh multimedia interaktif adalah multimedia pembelajaran interaktif, aplikasi game dan lain-lain

Beberapa kutipan lagi menjelaskan bahwa Multimedia mempunyai arti tidak hanya integrasi anatar teks dan grafik sederhana saja, tetapi dilengkapi dengan suara dan animasi. Untuk memahami konsep multimedia dan pembelajaran multimedia sebaiknya kita harus memahami terlebih dahulu apa yang dimaksud dengan multimedia dan manfaat dari multimedia (Hendi Hendratman, 2008 [7]).

\section{1) Bidang Multimedia}

Agus Suheri, (2006) [8] mengatakan Multimedia terdapat dari beberapa bidang, antara lain seperti yang dijelaskan adalaha :

a) Bidang Periklanan yang efektif juga interaktif

b) Bidang Pendidikan dalam penyampaian bahan pengajaran secara interaktif dan dapat mempermudah pembelajaran karena didukung oleh berbagai aspek suara, video, animasi, teks, dan grafik.

c) Bidang jaringan dan internet yang membantu dalam pembuatan website yang menarik, informatif, dan interaktif.

\section{2) Kemampuan Multimedia}

Kemampuan perubahan yang dilakukan dengan multimedia yaitu multimedia mampu mengubah :

a) Mengubah mengubah tempatkerja. Dengan adanya teleworking, parapekerja dapat melakukan pekerjaanya tidak harus dari kantor. Contoh software yang mendukung teleworking/telecommuting Netmeeting!

b) Mengubah carabelanja. Homes hopping/teleshopping dapat dilakukan dengan menggunakaninternet, kemudian barang datang dengan sendirinya.

c) Mengubah carabisnis. Nokia membuat bisnis telepon seluler, banyak perusahaan menggunakan sistem jual beli online, bank menggunakan cara online-banking.

d) Mengubah cara memperolehinformasi. Orangorang mulaimenggunakaninternet dan berbagai software untuk mencari informasi. Misalnya: membaca koran online, detik.com, menggunakan 
software kesehatan, belajar gitar dari software dan masih banyak lagi.

e) Mengubah carabelajar. Sekolah mulai menggunakan komputer multimedia, belajar online, menggunakan e-book.

f) Internet Multimedia juga mulai bersaing dengan televisi dan radio.

\section{G) Adobe Flash Cs3}

Adobe flash CS3 (dahulu bernama macromedia flash) adalah hasil akuisi dilakukan oleh Adobe oleh macromedia yang salah satu perangkat lunak komputer yang merupakan produk unggulan adobe sistems. Adobe flash memiliki kemampuan untuk membuat animasi mulai dari yang sederhana hingga kompleks. Adobe flash dapat menggabungkan gambar, suara, dan video ke dalam animasi yang dibuat. Berkas yang dihasilkan dari perangkat lunak ini mempunyai file extension .fla. file ini kemudian dapat dipublikasikan sehingga dihasilkan file .swf. file .swf inilah yang menjadi file final berisi animasi. File .swf harus dimainkan menggunakan softwere khusus, salah satunya flash player yang sudah terintegrasi pada saat instalasi program adobe flash CS3 (Hasrul, 2011 [6]).

\section{Metodologi PenElitian}

\section{A) Analisis Sistem}

Analisis Sistem merupakan penguraian dari sistem informasi yang utuh ke bagian-bagian komponennya yang dimaksud untuk mengidentifikasi dan mengevaluasi segala macam permasalahan dan hambatan dapat menjadi acuan untuk diusulkannya perbaikanperbaikan.

Sistem yang akan dibangun oleh penulis adalah pembelajaran Al-Qur'an untuk anak usia 4-8 tahun. Pembelajaran ini dirancang berdasarkan materi pembelajaran Al-Qur'an untuk mengenal huruf hijaiyah, hukum tajwid dan surat-surat pendek pada juz amma'. Pembelajaran ini dibuat dengan menggabungkan unsur teks, animasi, suara yang dikonversikan dalam bentuk exe dan software yang digunakan adalah Adobe Flash CS3.

\section{B) Perancangan Storyboard}

Storyboard adalah alur cerita atau sketsa/ skenario dari tampilan suatu aplikasi pada layar secara detail. Berikut ini adalah rancangan storyboard dari aplikasi pembelajaran Al-Qur'an yang penulis rancang.

Adapun storybord perancangan aplikasi media pembelajaran Al-Qur'an ini adalah sebagai berikut:

1) Aplikasi pembelajaran ini dimulai dari tampilan intro, dimana di dalam intro terdapat animasi tesk, tombol start dan animasi beberapa gambar.
2) Tampilan Peta Konsep, disini terdapat animasi teks, animasi gambar, dan beberapa tombol yaitu tombol menu Biodata dan tombol menu utama.

3) Pada tombol menu biodata terdapat animasi gambar, animasi teks dan tombol back.

4) Pada tombol Huruf Hijaiyah disini terdapat 30 huruf hijaiyah yang berawal dari alif sampai dengan ya. Apabila diklik hurufnya akan terdapat suara bacaan tentang huruf tersebut.

5) Pada menu Hukum Tajwid disini terdapat penjelasan mengenai hukum-hukum bacaan AlQur'an yaitu : Idghaam, Waqaf, Ikhfa, Mad, IzhHaar, Qalqalah, Iqlaab.

6) Pada menu surat-surat pendek akan terdapat surat Al-Fatiha, Al-Ikhlash, Al-Laahab, An-Nash, AlMa'un, Al-Kafirun, An-Nashr, Al-Falaq. Dalam menu ini juga terdapat tulisan bahasa arab dan bahasa Indonesia dari surat tersebut.

7) Pada menu Next akan membuat pengguna aplikasi meneruskan tampilan selanjutnya.

8) Pada menu Back akan membuat pengguna aplikasi kembali dari tampilan.

9) Pada menu Out akan membuat pengguna aplikasi keluar dari aplikasi.

\section{C) Perancangan Sistem}

Perancangan sistem adalah suatu bagian dari metodologi pengembangan suatu perangkat lunak yang dilakukan setelah tahapan untuk memberikan gambaran secara terperinci. Perancangan sistem merupakan tahapan dari siklus pengembangan sistem yang didefenisikan dari kebutuhan-kebutuhan fungsional dan persiapan untuk rancang bangun implementasi yang menggambarkan bagaimana suatu sistem dibentuk, bisa berupa penggambaran, perancangan dan pembuatan sketsa atau pengaturan dari beberapa elemen yang terpisah ke dalam satu kesatuan yang utuh dan memiliki fungsi, juga menyangkut konfigurasi dari komponen-komponen perangkat keras dan perangkat lunak dari suatu sistem.

\section{D) Perancangan Flowchart}

Flowchart perancangan sistem yang digunakan ditunjukkan pada Gambar 1.

\section{IMPLEMENTASI}

Implementasi merupakan suatu langkah dalam membangun sebuah perangkat lunak. Berikut akan dijelaskan implementasi yang dilakukan dalam merancang perangkat lunak pembelajaran Al-Qur'an.

\section{A) Pengujian Perangkat Lunak}

Pengujian adalah proses eksekusi suatu perangkat lunak dengan maksud menemukan kesalahan. Pengu- 


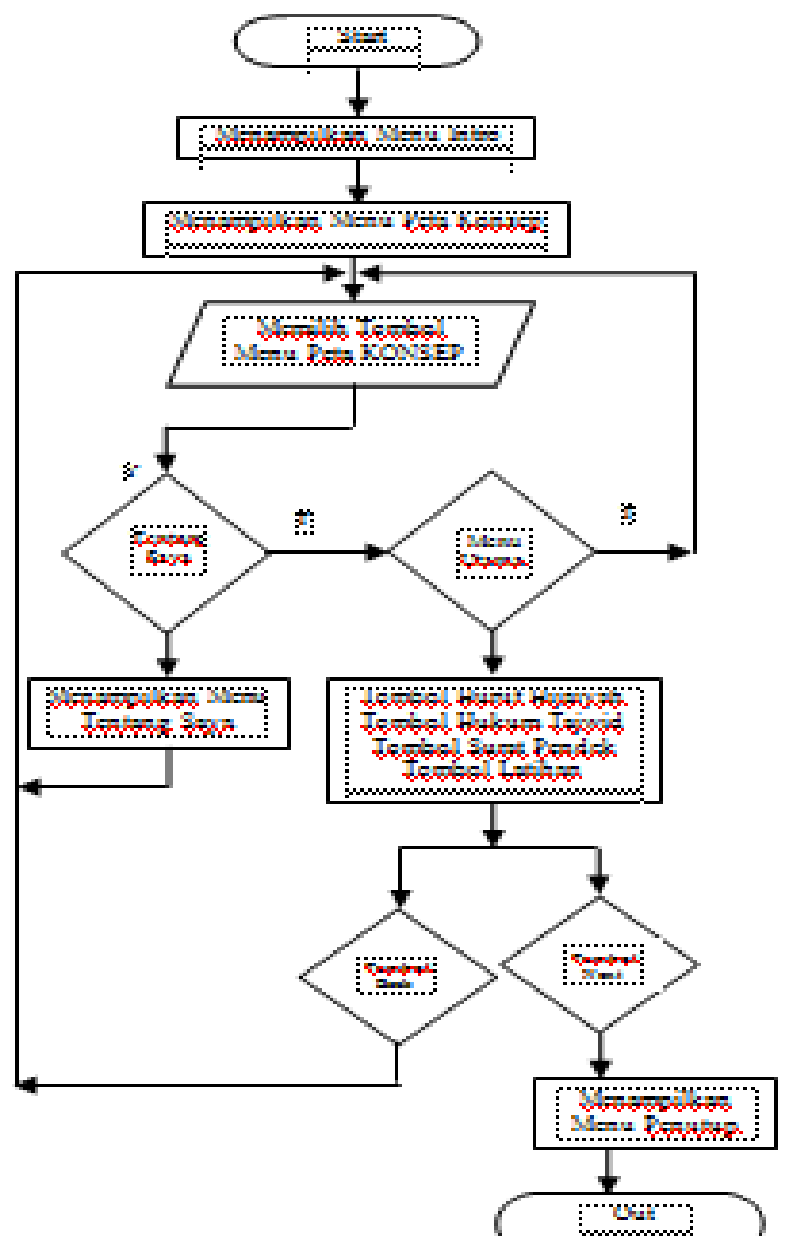

Gambar 1. Flowchart Perancangan Sistem

jian diujikan untuk melihat apakah perangkat lunak yang dibangun telah berjalan dan memberikan hasil yang sesuai dengan keinginan. Pengujian dilakukan untuk mengetahui apakah perangkat lunak dapat mendukung anak untuk dapat mempelajari Al-Qur'an sesuai yang diharapkan.

\section{1) Tampilan Intro}

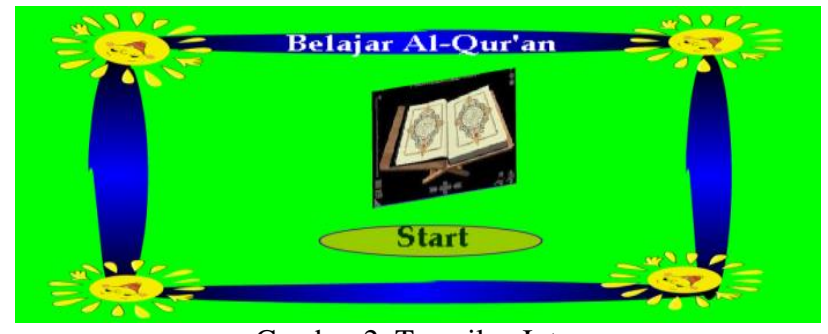

Gambar 2. Tampilan Intro

Tampilan intro digunakan sebagai tampilan awal dari rancangan perangkat lunak yang dibangun. Pada tampilan intro terdapat important suara "Assalamu'alaikum adik-adik hari ini kita akan belajar AlQur'an, selamat belajar ya!!!" dan animasi teks "Belajar Al-Qur'an" juga animasi gambar Al-Qur'an dan kartun, dan tombol start untuk masuk ke tampilan peta konsep.

\section{2) Tampilan Menu Peta Konsep}

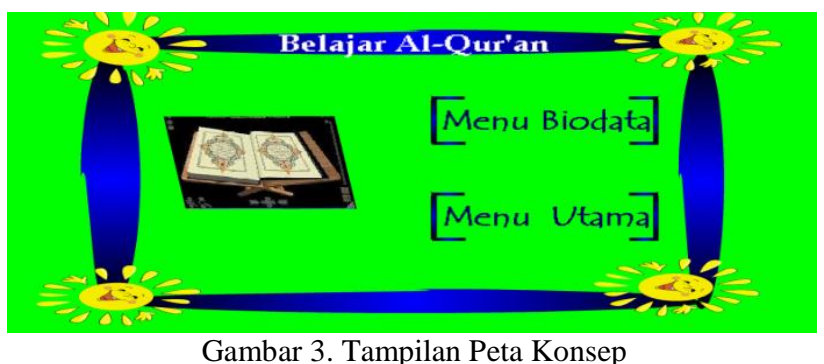

Pada tampilan Peta Konsep terdapat animasi teks "Belajar Al-Qur'an" animasi gambar Al-Qur'an, dan dua tombol, yaitu tombol menu biodata dan menu utama. User disuruh memilih dua tombol yang ada pada peta konsep, yang apabila mengklik tombol biodata maka akan menampilkan menu tentang biodata penulis dan jika mengklik menu utama maka akan menampilkan menu utama yang berisi tombol Huruf Hijaiyah, Hukum Tajwid, Surat pendek dan latihan.

\section{3) Tampilan Biodata}

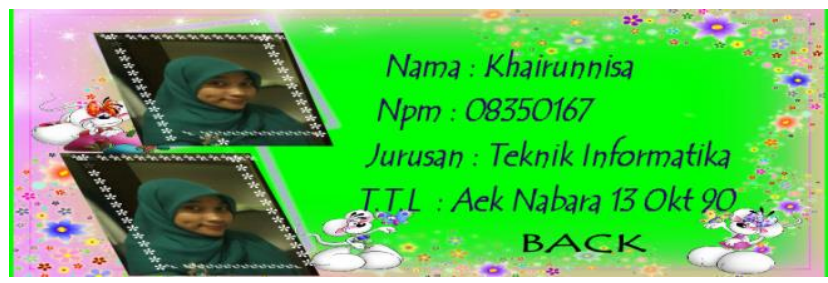

Gambar 4. Tampilan Menu Biodata

Pada tampilan menu biodata ini terdapat animasi teks biodata dan animasi gambar dan back apabila user ingin kembali ke menu peta konsep dan memilih tobol yang lainnya.

\section{4) Tampilan Menu Utama}

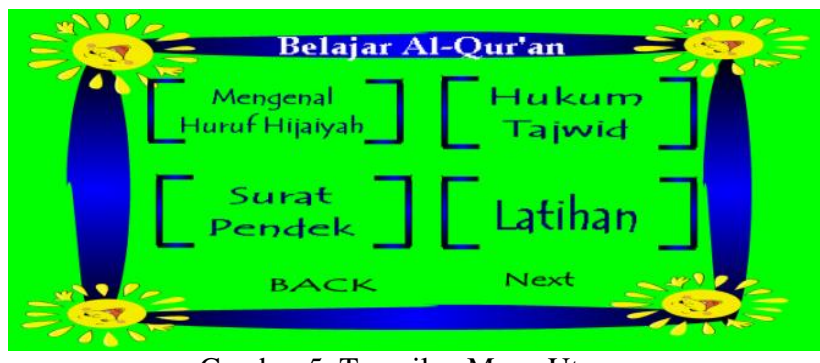

Gambar 5. Tampilan Menu Utama

Pada tampilan menu utama terdapat animasi teks "Belajar Al-Qur'an" dan 4 tombol yaitu mengenal huruf hijaiyah, hukum tajwid, surat-surat pendek dan latihan. Apabila memilih salah satu tombol tersebut maka akan menampilkan menu yang diinginkan, dan tombol back untuk kempali ke menu peta konsep sedangkan tombol next untuk lanjut ke menu penutup. 


\section{5) Tampilan Huruf Hijaiyah}

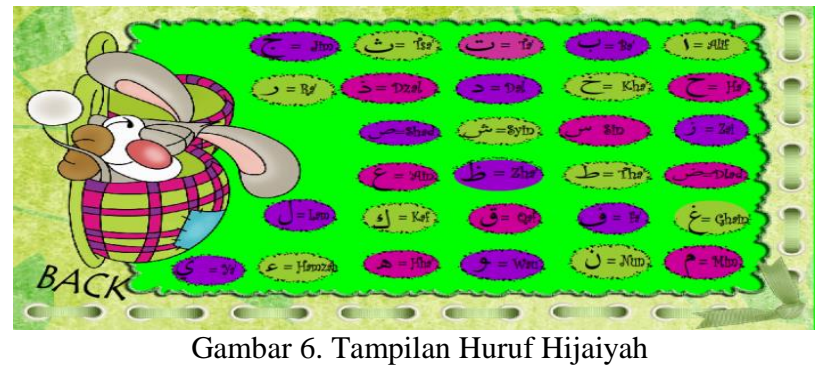

Pada tampilan huruf hijaiyah ini user disuruh mengklik tombol yang sudah ada, apabila mengklik salah satu tombol huruf hijaiyah maka akan mengeluarkan suara sesuai dengan hurufnya, tombol back untuk kembali kemenu utama.

\section{6) Tampilan menu hukum tajwid}

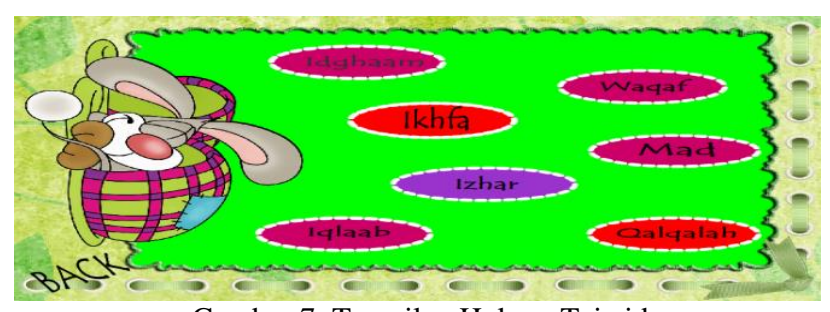

Gambar 7. Tampilan Hukum Tajwid

Pada tampilan ini terdapat beberapa tombol hukum tajwid, apabila user memilih salah satu hukum maka akan menampilkan materi sesuai yang dipilih dengan inportan suaranya juga. Tombol back untuk kembali ke menu utama.

\section{7) Tampilan Materi Hukum Idghaam}

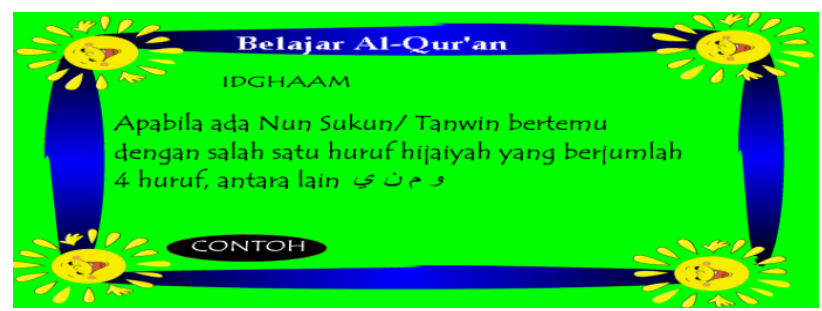

Gambar 8. Tampilan Maateri Idghaam

Pada menu ini terdapat materi tentang hukum idghaam, dan important suara, dan tombol contoh untuk menampilkan contoh hukum idghaan.

\section{8) Tampilan Contoh Idghaam}

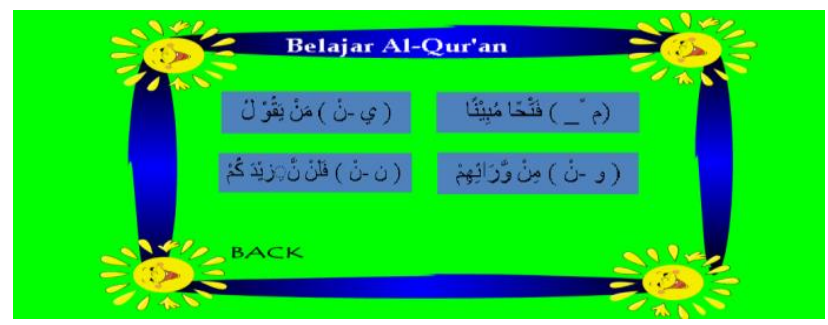

Gambar 9. Tampilkan contoh hukum idhaam
Pada menu ini menampilkan empat tombol contoh hukum idhaam, apabila diklik maka akan mengeluarkan suara sesuai dengan bacaannya. Tombol back akan kembali kemenu hukum tajwid.

\section{9) Tampilan Hukum Waqaf}

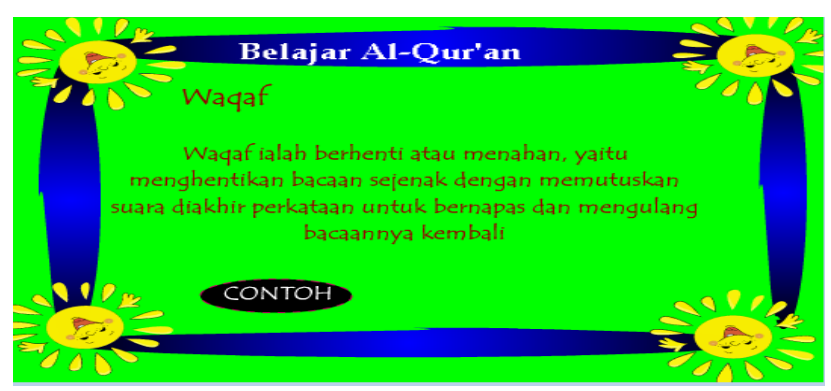

Gambar 10. Tampilan Materi Hukum Waqaf

Pada menu ini terdapat materi tentang hukum waqaf, dan important suara dan tombol contoh untuk menampilakn contoh hukum waqaf.

\section{0) Tampilan Contoh Waqaf}

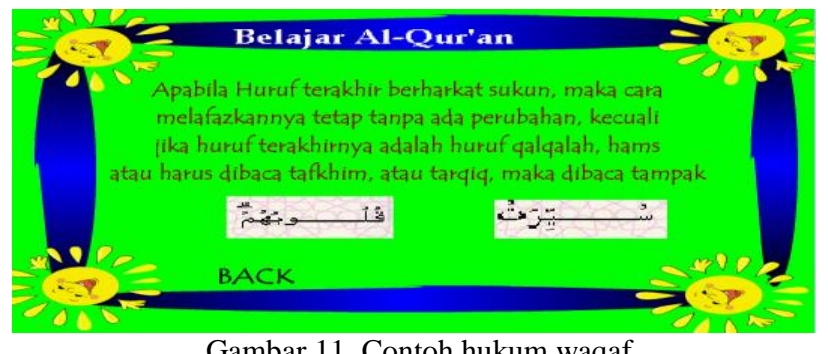

Gambar 11. Contoh hukum waqaf

Pada menu ini menampilkan dua contoh hukum waqaf yang apabila diklik amak akan mengeluarkan suara bacaan dari contoh tersebut. Tombol back untuk kembali kemenu hukum tajwid.

\section{1) Tampilan Materi Ikhfa}

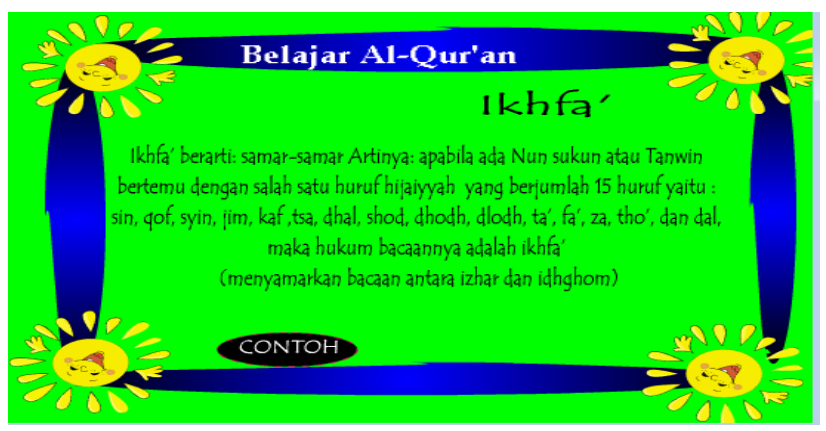

Gambar 12. Materi Hukum Ikhfa

Pada menu ini terdapat materi tentang hukum ikhfa, dan important suara, dan tombol contoh untuk menampilkan contoh dari hukum ikhfa. 


\section{2) Tampilan Contoh Ikhfa}

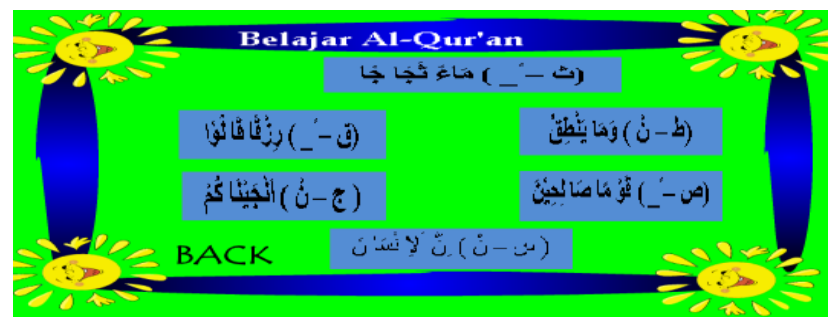

Gambar 13. Contoh Hukum Ikhfa

Pada menu ini menampilkan enam buah contoh hukum ikhfa yang apabila diklik maka akan mengeluarkan suara bacaan dari contoh tersebut. Tombol back untuk kembali ke menu hukum tajwid.

\section{3) Tampilkan Hukum Mad}

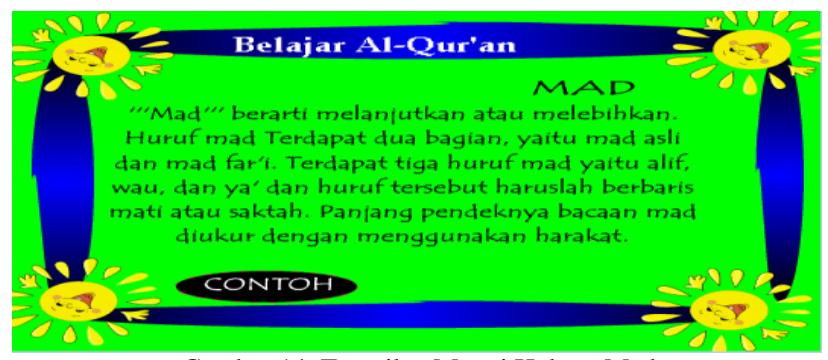

Gambar 14. Tampilan Materi Hukum Mad

Pada menu ini terdapat materi tentang hukum mad, dan important suara dan tombol contoh untuk menampilkan contoh hukum mad.

\section{4) Tampilan Contoh Mad}

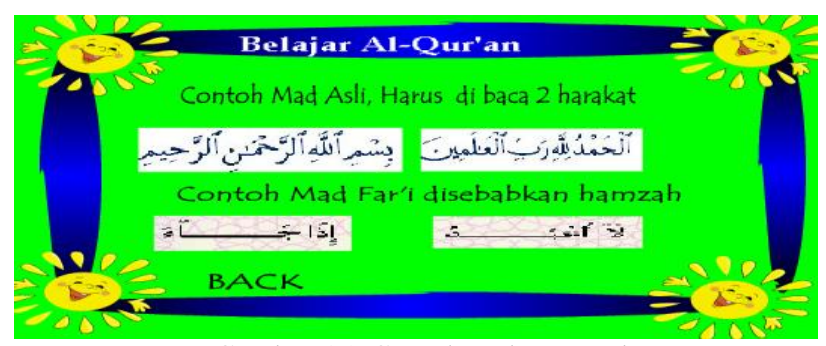

Gambar 15. Contoh Hukum Mad

Pada menu ini menampilkan contoh hukum mad yang apabila diklik maka akan mengeluarkan suara bacaan dari contoh tersebut. Tombol back untuk kembali ke menu hukum tajwid.

\section{5) Tampilan Hukum Izhar}

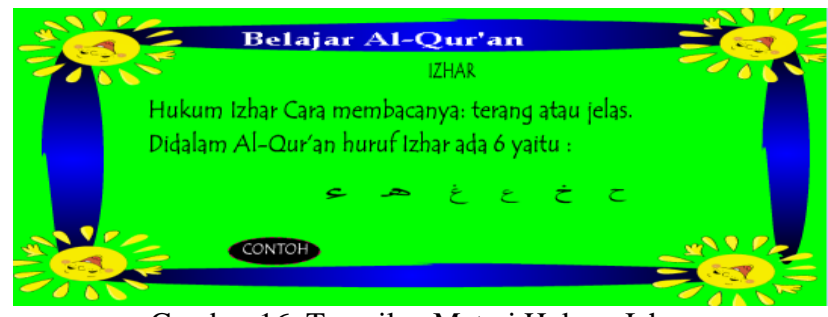

Gambar 16. Tampilan Materi Hukum Izhar
Pada menu ini terdapat materi tentang hukum Izhar, dan important suara dan tombol contoh untuk menampilkan contoh hukum Izhar.

\section{6) Tampilan Contoh Hukum Izhar}

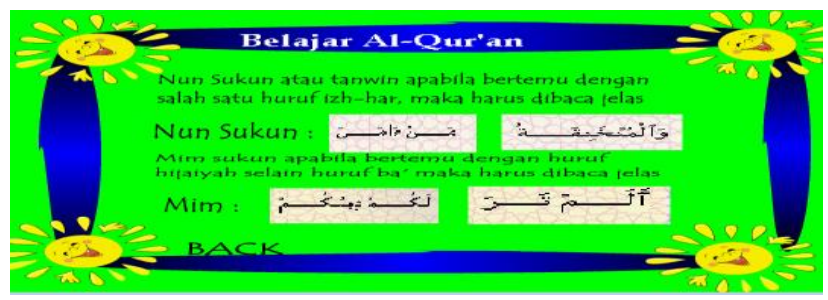

Gambar 17. Contoh Hukum Izhar

Pada menu ini menampilkan contoh hukum izhar yang apabila diklik maka akan mengeluarkan suara bacaan dari contoh tersebut. Tombol back untuk kembali ke menu hukum tajwid.

\section{7) Tampilan Hukum Iqlaab}

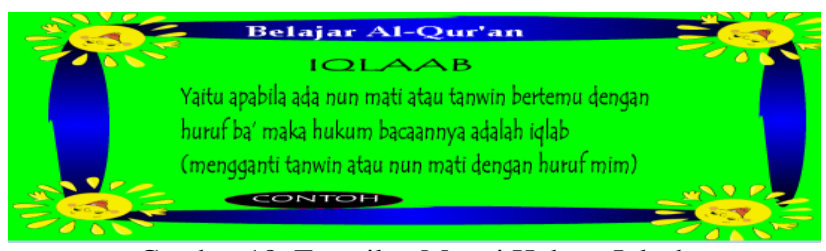

Gambar 18. Tampilan Materi Hukum Iqlaab

Pada menu ini terdapat materi tentang hukum Iqlaab, dan important suara dan tombol contoh untuk menampilkan contoh hukum Iqlaab.

\section{8) Tampilan Contoh Iqlaab}

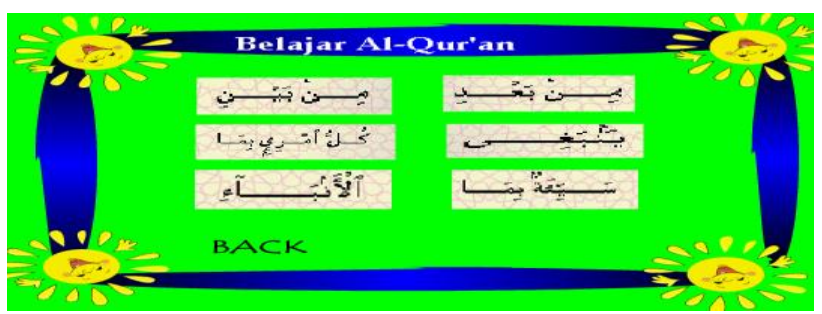

Gambar 19. Contoh Tampilan Iqlaab

Pada menu ini menampilkan contoh hukum iqlaab yang apabila diklik maka akan mengeluarkan suara bacaan dari contoh tersebut. Tombol back untuk kembali ke menu hukum tajwid.

\section{9) Tampilan Materi Hukum Qalqalah}

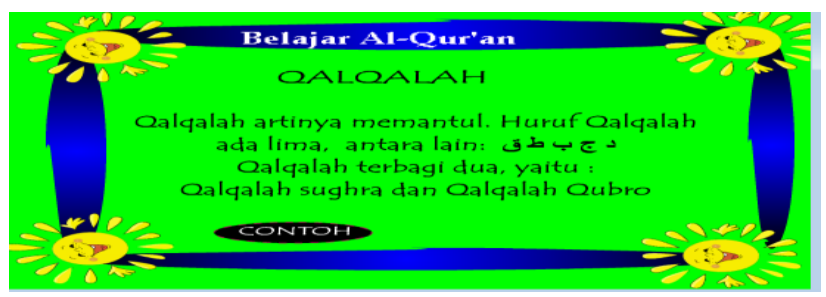

Gambar 20 Tampilan Materi Hukum Qalqalah 
Pada menu ini terdapat materi tentang hukum Qalqalah, dan important suara dan tombol contoh untuk menampilkan contoh hukum Qalqalah.

\section{0) Tampilan Contoh Qalqalah}

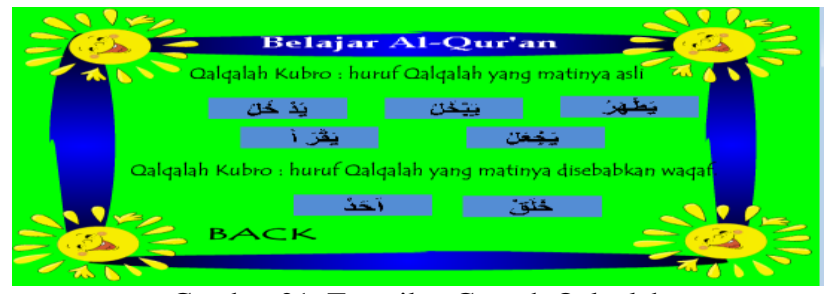

Gambar 21. Tampilan Contoh Qalqalah

Pada menu ini menampilkan contoh hukum Qalqalah yang apabila diklik maka akan mengeluarkan suara bacaan dari contoh tersebut. Tombol back untuk kembali ke menu hukum tajwid.

\section{1) Tampilan Menu Surat Pendek}

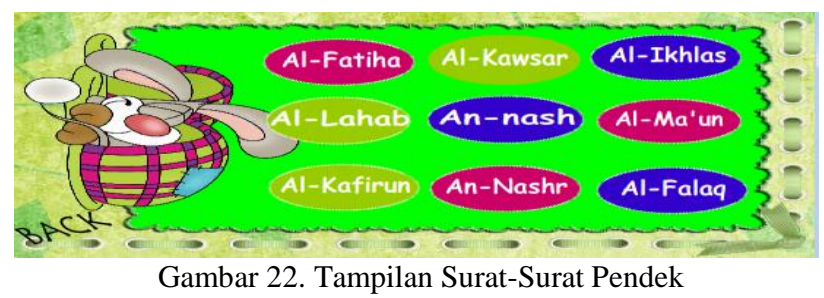

Pada tampilan ini terdapat tombol nama-nama surat pendek, apabila diklik salah satu surat maka akan menampilkan tampilah surat yang dipilih. Tombol back untuk kembali ke menu utama.

\section{2) Tampilan Surat Al-Fatiha}

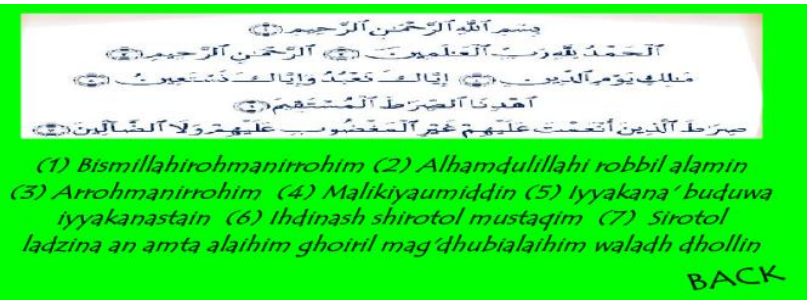

Gambar 23. Tampilan Surat Al-Fatiha

Pada Tampilan ini akan mengeluarkan suara Murattal Al-Fatiha, dan tombol Back untuk kembali ke Menu Surat Pendek.

\section{3) Tampilan Surat Al-Kawsar}

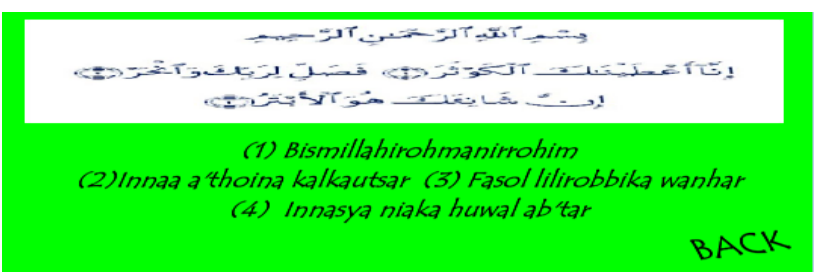

Gambar 24. Tampilan Surat Al-Kawsar
Pada Tampilan ini akan mengeluarkan suara Murattal Al-Kawsar, dan tombol Back untuk kembali ke Menu Surat Pendek.

\section{4) Tampilan Surat Al-Ikhlash}

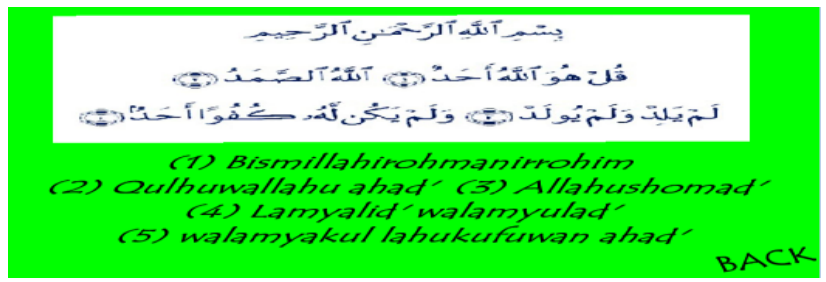

Gambar 25. Tampilan Surat Al-Ikhlash

Pada Tampilan ini akan mengeluarkan suara Murattal Al-Ikhlash, dan tombol Back untuk kembali ke Menu Surat Pendek.

\section{5) Tampilan Surat Al-Lahaab}

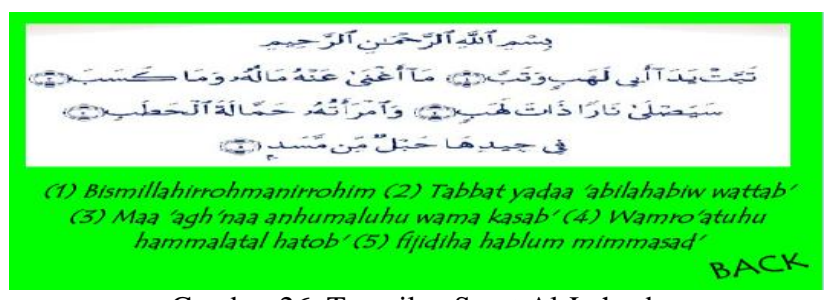

Gambar 26. Tampilan Surat Al-Lahaab

Pada Tampilan ini akan mengeluarkan suara Murattal Al-Kawsar, dan tombol Back untuk kembali ke Menu Surat Pendek.

\section{6) Tampilan Surat An-Nash}

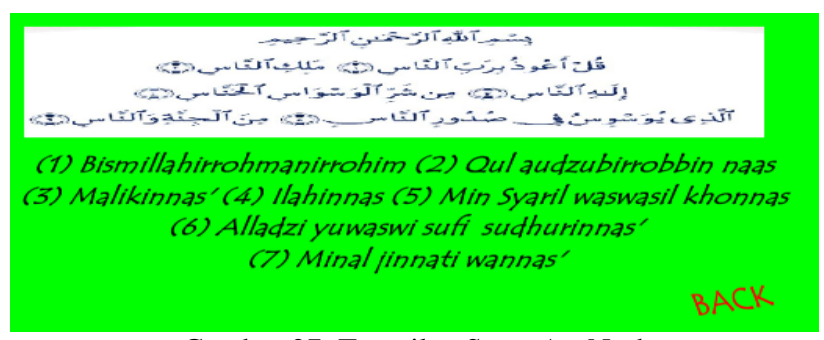

Gambar 27. Tampilan Surat An-Nash

Pada Tampilan ini akan mengeluarkan suara Murattal An-Nash, dan tombol Back untuk kembali ke Menu Surat Pendek.

\section{7) Tampilan Surat Al-Ma'un}

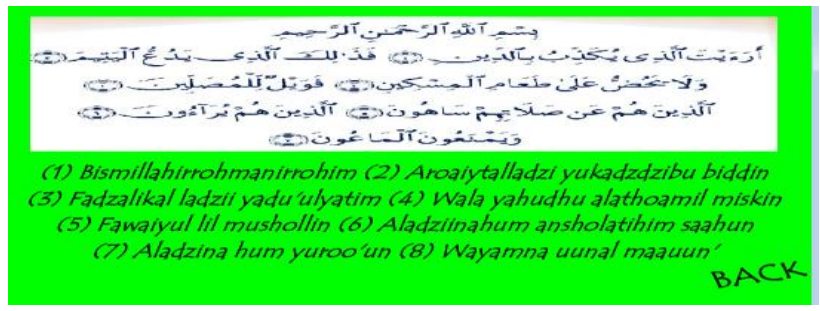

Gambar 28. Tampilan Surat Al-Ma'un 
Pada Tampilan ini akan mengeluarkan suara Murattal Al-Ma'un, dan tombol Back untuk kembali ke Menu Surat Pendek.

\section{8) Tampilan Surat Al-Kafirun}

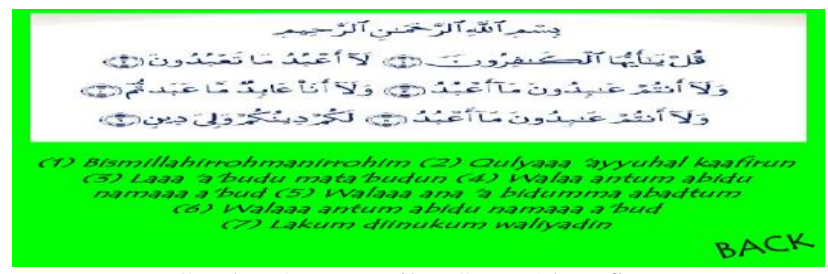

Gambar 29. Tampilan Surat Al-Kafirun

Pada Tampilan ini akan mengeluarkan suara Murattal Al-Kafirun, dan tombol Back untuk kembali ke Menu Surat Pendek.

\section{9) Tampilan Surat An-Nashr}

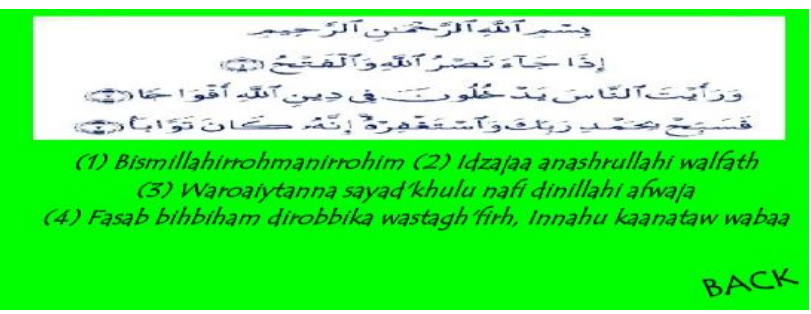

Gambar 30. Tampilan Surat An-Nashr

Pada Tampilan ini akan mengeluarkan suara Murattal An-Nashr, dan tombol Back untuk kembali ke Menu Surat Pendek.

\section{0) Tampilan Surat Al-Falaq}

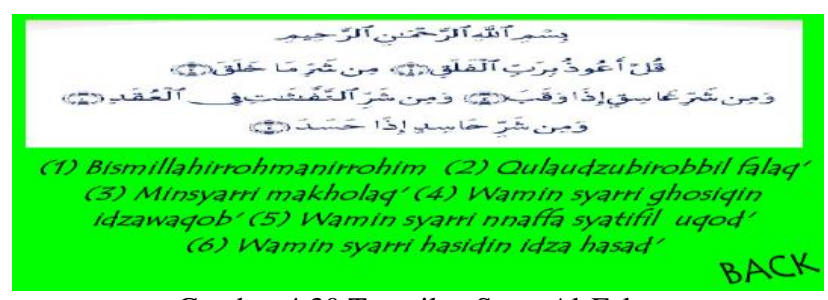

Gambar 4.30 Tampilan Surat Al-Falaq

Pada Tampilan ini akan mengeluarkan suara Murattal An-Nashr, dan tombol Back untuk kembali ke Menu Surat Pendek.

\section{1) Tampilan Menu Latihan}

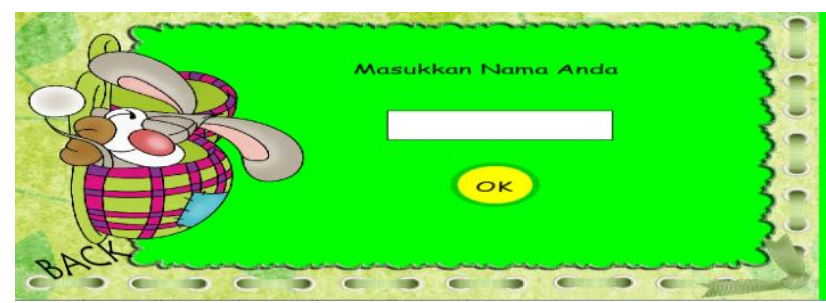

Gambar 32. Tampilan Menu Latihan

Merancang Perangkat Lunak Pembelajaran Al Qur'an ...
Pada menu ini terdapat inputan teks untuk mengisi nama user dan tombol Ok untuk kemenu Soal, dan tombol Back untuk kembali ke menu utama.

\section{2) Tampilan Menu Soal Pertama}

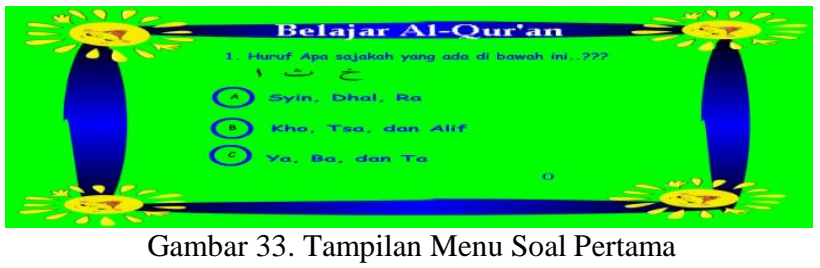

Pada tampilan ini terdapat soal dan pilihan jawabannya, jika mengklik pilihan jawaban yang benar maka akan menampilkan score 10 .

\section{3) Tampilan Menu Soal Kedua}

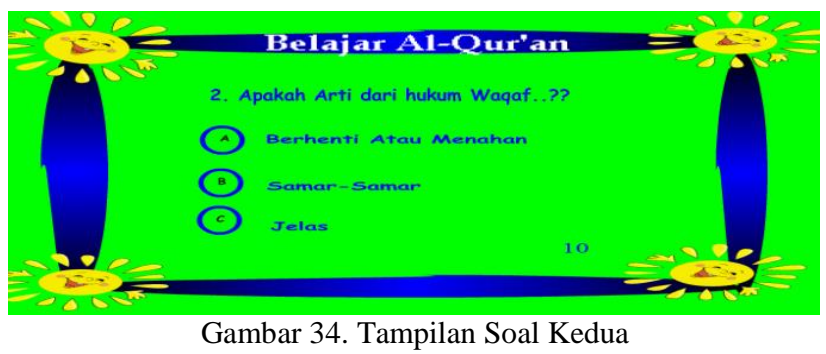

Pada tampilan ini terdapat soal dan pilihan jawabannya, jika mengklik pilihan jawabannya dan jika benar maka akan menambah score 10 lagi. Begitu seterusnya sampai soal ke Lima Belas.

\section{4) Tampilan Menu Hasil}

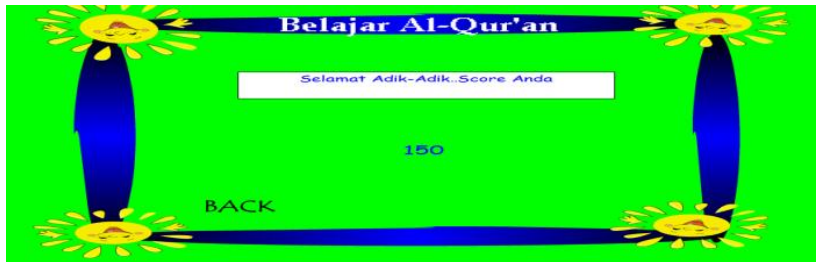

Gambar 35. Tampilan Menu Hasil

Pada Menu ini akan menampilan berapa Score yang didapat, dari menjawwab latihan sebelumnya, juga terdapat importan suara, dan tombol back untuk kembali ke menu utama.

\section{5) Tampilan Menu Penutup}

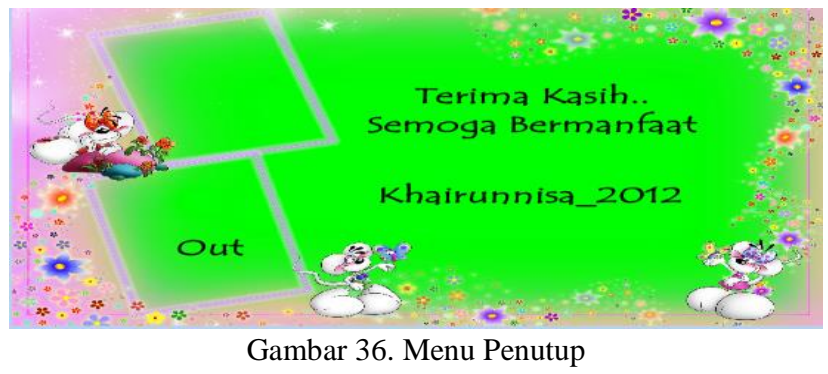

ISSN $1858-2680$ 
Pada tampilan ini terdapat animasi teks dan inportan suara, dan tombol Out untuk enutup aplikasi perancangan perangkat lunak ini.

\section{Penutur}

\section{A) Kesimpulan}

Dari hasil perancangan dan merancang perangkat lunak pembelajaran Al-Qur'an dengan metode interaktif untuk anak dengan menggunakan adobe flash Cs3, maka dapat disimpulkan bahwa :

1) Pembelajaran berbasis multimedia merupakan salah satu aplikasi yang besar manfaatnya, karena dapat membantu sistem pendidikan yang efektif.

2) Perangkat Lunak yang penulis bangun dapat membantu seorang anak yang ingin belajar AlQur'an dan lebih informative.

3) Dengan menggunakan perangkat lunak ini maka user dapat mengenal huruf-huruf hijaiyah, hukum tajwid, dan surat-surat pendek pada juz amma'

4) Dapat mengevaluasi pembelajaran yang ada dengan menguji soal latihan yang telah disediakan.

\section{B) Saran}

Adapun saran yang dapat disampaikan untuk pengenbangan perangkat lunak lebih lanjut diharapkan kepada user untuk sering mengulang pembelajaran rancangan perangkat lunak ini, dan mengikuti bacaan-bacaan yang sudah ada. Dan dapat belajar dengan mandiri tanpa harus didampingi seorang guru. Perangkat lunak pembelajaran Al-Qur'an berbasis Multimedia untuk anak, hendaknya dapat dikembangkan juga pada mata pembelajaran yang lain sebagai bahan alternative sumber belajar yang lebih menarik dan interaktif.

\section{DAFTAR PUSTAKA}

[1] Lisda dan Seto Mulyadi.(2014) "Pembuatan Animasi Pembelajaran Berbasis Multimedia Mata Kuliah Psikologi Perkembangan Menggunakan Adobe flash cs3". Universitas Gunadarma Depok.

[2] M.Yanyan dan Irawan. (2013) "Pembangunan Aplikasi Bantu Dalam Menghafal Al-Qur'an Berbasis Mobile". Universitas Komputer Indonesia Bandung.

[3] Hassan bin Shihabuddin Shuhur.(2008) "Ilmu Tajwid.Malaysia: RiwayatHafs 'An'Aasim”

[4] Tri Sanjaya.(2013) "PENGEMBANGAN MEDIA PEMBELAJARAN PNEUMATIK DAN HIDROLIK BERBASIS ADOBE FLASH CS3 professional program studi diploma 3 teknik otomotif universitas negeri yogyakarta" Yogyakarta

[5] Rista Apriana.(2009) "Hubungan Pendidikan Anak Usia Dini (PAUD) dengan Perkembangan Kognitif Anak Usia Prasekolah di Kelurahan Tinjomoyo Kecamatan Banyu maik”. Semarang : Fakultas Kedokteran Universitas Diponegoro.

[6] Hasrul.(2011) "Desain Media Pembelajaran Animasi Berbasis Adobe Flash Cs3 Pada Mata Kuliah Instalasi Listrik 2”.Vol.2 N0.3

[7] Hendratman, Hendi.(2008) "The Magic Book of Graphics Design Animation \&Multimedia". Jakarta: Penerbit Informatika.

[8] Agus Suheri. (2006) "Animasi Multimedia Pembelajaran”. Vol.2 No.1 